Note

\title{
Changes in Serum Levels of IGF-I and IGFBP-3 in Children with Chronic Renal Failure ${ }^{\#}$
}

\author{
Necla Buyan*, Peyami CínAZ***, Enver HasanoǦlu*, Nahide GÖKÇORA**, \\ AND ZELAL BIRCAN* \\ Gazi University, Faculty of Medicine, **Department of Pediatrics and Nuclear Medicine, \\ *Unit of Nephrology and ***Endocrinology, Ankara 06450, Turkey
}

\begin{abstract}
The significance of serum insulin-like growth factor I (IGF-I) and insulin-like growth factor binding protein 3 (IGFBP-3) levels in uremia is still controversial. In this study we measured serum IGFI by immunoradiometric assay (IRMA) and IGFBP-3 levels by specific radioimmunoassay (RIA) in 28 children (aged 3-16 years) with end-stage $(n=14$, on hemodialysis) and pre-terminal renal failure $(n=14)$ and in 15 age-matched healthy children. Thyroid function of the patients was also investigated and GHstimulation tests with L-Dopa and insulin were performed. Neither IGF-I nor IGFBP-3 levels significantly correlated with mean height SDS for bone age or for chronological age in either non dialysis patients or pubertal $(n=10)$ or prepubertal patients $(n=18)$. These data was consistent with the concept that growth in CRF was not related to abnormalities in serum IGF-I or IGFBP-3 levels.
\end{abstract}

Key words : Chronic renal failure, Insulin-like growth factor I, Insulin-like growth factor binding protein 3, Uremia

(Endocrine Journal 42: 429-433, 1995)

GROWTH failure is a common problem in children with chronic renal failure (CRF). It could be explained by three factors in the GH/IGF-axis. First, growth failure occurs despite normal or elevated levels of $\mathrm{GH}$, suggesting impaired $\mathrm{GH}$ action rather than low $\mathrm{GH}$ production [1]. The clinical and experimental data indicate that a reduced expression of the GH receptor at target organs may be one of the reasons for GH resistance in uremia [2]. Second, abnormal IGF generation may be responsible for impaired growth in uremia, because GH is thought to stimulate skeletal growth indirectly through the generation of IGFs. Insulin-like growth factor (IGF)-I and IGF-II are low molecular weight peptides that mediate the mitogenic actions

Received : January 20, 1994

Accepted : January 20, 1995

Correspondence to : Dr. Necla BUYAN, Eşref Özant Sok. 1/2, Dostlar Apt., OR-AN 06450 Ankara-Turkey

\#This research was presented at the XXXth Congress of EDTA and ERA, Sept 5-8, 1993, Glasgow, Scotland. of growth hormone [3]. IGF-I is the major growth factor involved in postnatal growth [4]. Measurements of IGF-I by radioimmunoassay (RIA) have been reported, as low [5, 6], high [7] or normal [810] levels in uremic patients. Third, it has been postulated that the high levels of low molecular weight unsaturated IGF-binding protein (IGFBP) may function as a growth inhibitor in CRF. More than $95 \%$ of serum IGF-I and II are bound to IGFBP-3 and the acid labile subunit [11]. Serum IGFBP-3 levels might reflect increased IGF-binding activity, that may decrease free IGF-I levels and growth retardation in uremia $[1,3,12]$.

In this study, serum IGF-I and IGFBP-3 levels were measured by specific RIAs in children with CRF in order to clarify the role of these parameters in growth failure in uremia. The aim of the study was to investigate whether or not IGF-I and IGFBP-3 levels in the patients differ from those in age-matched healthy children, and also examine the relationship of those levels with height and pubertal status. 


\section{Subjects and Methods}

We studied 28 children, 15 boys and 13 girls, aged 3-16 years (median age 10 years). Fourteen patients were treating with hemodialysis (HD) and the remaining 14 showed GFR=5-50 $\mathrm{ml} / \mathrm{min} / 1.73$ $\mathrm{m}^{2}$ body surface area. Eighteen children were in the pre-pubertal (seven on HD) and ten were in the pubertal stage (six on HD). Primary diseases of the patients were: urinary tract abnormalities $(n=4)$, glomerulonephritis $(n=10)$, pyelonephritis $(n=7)$ and unknown origin $(n=7)$.

Glomerular filtration rate (GFR) was determined from the creatinine clearance with the formula: Creatinine clearance $\left(\mathrm{ml} / \mathrm{min}\right.$ per $\left.1.73 \mathrm{~m}^{2}\right)=\mathrm{k} \times$ height $(\mathrm{cm}) /$ plasma creatinine $(\mathrm{mg} / \mathrm{d} l)$. " $\mathrm{k}$ " was calculated from the degree of malnutrition in our patients [13]. Height was expressed as the standard deviation score (SDS) for chronological or bone age (SDSCA, SDSBA) using normal data from Tanner et al. [14]. Bone age was determined with the Greulich and Pyle atlas by a radiologist [15]. The pubertal stage was determined by means of the staging system of Tanner [16]. We also investigated thyroid function (total $\mathrm{T}_{3}$, total $\mathrm{T}_{4}$, free $\mathrm{T}_{3}$, free $\mathrm{T}_{4}$ and TSH) in all the patients. Total $\mathrm{T}_{3}$, total $T_{4}$, free $T_{3}$ and free $T_{4}$ were measured by RIA and TSH was measured by IRMA.
GH levels after the stimulation test with L-Dopa and insulin were measured by RIA with a commercially available kit DPC (Diagnostic Products Corporation). The lowest and highest limits of detection of this assay were $0 \mathrm{ng} / \mathrm{ml}$ and $30 \mathrm{ng} / \mathrm{ml}$, respectively.

The total (carrier protein bound plus free) serum IGF-I concentrations were measured by a specific IRMA with commercially available kit DSL (Diagnostic System Laboratories Inc. Webster, Texas). The extraction was performed by acidifying the serum to dissociate IGF-I from its binding proteins. The lowest detectable level of IGF-I that could be distinguished from the $0 \mathrm{ng} / \mathrm{ml}$ IGF-I standard was $3 \mathrm{ng} / \mathrm{ml}$ at the $95 \%$ confidence limit. The inter and intra-assay coefficients of variation obtained with sera from patients with CRF were $7.6 \%$ and $7.2 \%$, respectively.

The levels of IGFBP-3 were measured by a specific RIA with the same commercial corporation kit (DSL Webster, Texas). All samples were diluted 1:100 with IGFBP-3 sample prior to the assay (10 $\mu l$ serum $+1 \mathrm{ml}$ IGFBP-3 sample Diluent). The lowest detectable level of IGFBP-3 that could be distinguished from the $0 \mathrm{ng} / \mathrm{ml}$ IGFBP-3 standard was $1.15 \mathrm{ng} / \mathrm{ml}$ at the $95 \%$ confidence limit. The inter and intra-assay coefficients of variation obtained with sera from patients with CRF were $6.7 \%$ and $3.5 \%$, respectively.

Table 1. SDS for bone age and chronological age and the results of GH stimulation tests and mean GFR values in the patients with CRF

\begin{tabular}{|c|c|c|c|c|c|}
\hline \multirow{2}{*}{$\begin{array}{l}\text { Patients } \\
(n=28)\end{array}$} & \multirow{2}{*}{ SDSCA } & \multirow{2}{*}{ SDSBA } & \multicolumn{2}{|c|}{$\mathrm{GH}(\mathrm{ng} / \mathrm{m} l)$} & \multirow{2}{*}{$\begin{array}{c}\text { GFR } \\
\left(\mathrm{ml} / \mathrm{min} \text { per } 1.73 \mathrm{~m}^{2}\right)\end{array}$} \\
\hline & & & L-Dopa & Insuline & \\
\hline $\begin{array}{l}\text { Prepubertal patients } \\
\qquad(\mathrm{n}=18)\end{array}$ & $\begin{array}{c}-3.07 \pm 1.43 \\
(-5.52 \text { to }-0.82)\end{array}$ & $\begin{array}{c}0.64 \pm 2.13 \\
(-2.04 \text { to } 4.7)\end{array}$ & $20.97 \pm 17.49$ & $24.32 \pm 18.78$ & $21.83 \pm 4.51$ \\
\hline $\begin{array}{l}\text { Pubertal patients } \\
\qquad(\mathrm{n}=10)\end{array}$ & $\begin{array}{l}-2.15 \pm 1.42 \\
(-4.34 \text { to } 0.47)\end{array}$ & $\begin{array}{l}-0.18 \pm 2.0 \\
(-2.86 \text { to } 2.54)\end{array}$ & $20.06 \pm 11.20$ & $17.90 \pm 14.44$ & $13.3 \pm 19.49$ \\
\hline $\begin{array}{l}\text { Dialysis patients } \\
\qquad(\mathrm{n}=14)\end{array}$ & $\begin{array}{l}-2.43 \pm 1.69 \\
(-5.27 \text { to } 0.47)\end{array}$ & $\begin{array}{c}0.46 \pm 2.34 \\
(-2.86 \text { to } 4.7)\end{array}$ & $21.41 \pm 15.98$ & $26.02 \pm 21.68$ & $3.6 \pm 0.37$ \\
\hline $\begin{array}{l}\text { Non-dialysis patients } \\
\qquad(\mathrm{n}=14)\end{array}$ & $\begin{array}{c}-3.03 \pm 1.25 \\
(-5.22 \text { to }-0.82)\end{array}$ & $\begin{array}{c}0.27 \pm 1.93 \\
(-3.3 \text { to } 3.96)\end{array}$ & $20.00 \pm 15.40$ & $18.73 \pm 12.52$ & $34.21 \pm 4.33$ \\
\hline
\end{tabular}

SDSCA, Standard deviation score for chronological age; SDSBA, Standard deviation score for bone age; GFR, Glomerular filtration rate. $\mathrm{GH}$ levels are shown as the maximum levels after each stimulation test. 


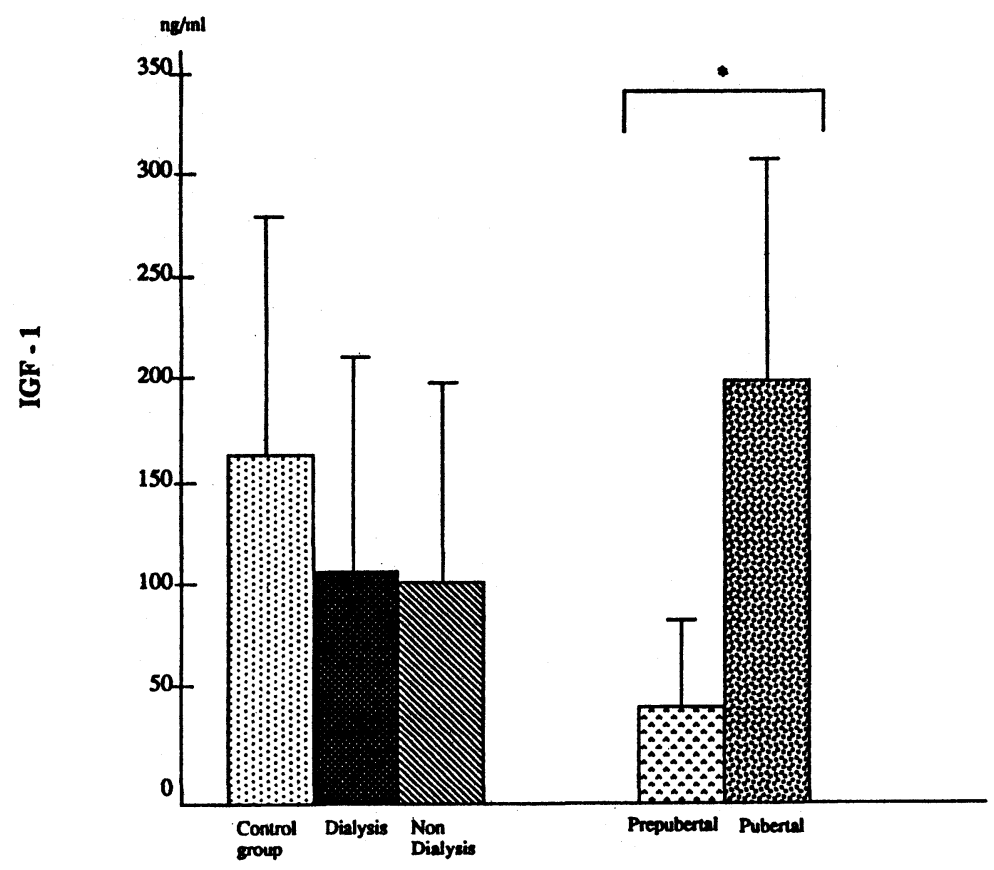

Fig. 1. Serum IGF-I levels in the patients with chronic renal failure and the control group $\left({ }^{*} P<0.001\right)$.

We informed the parents about this plan and got their consent before the study.

\section{Data analysis}

Data were presented as the mean \pm standard deviation. Student's $t$-test, Mann-Whitney $U$ test and Kruskal Wallis one way ANOVA were used to assess the significance of differences between the study groups.

\section{Results}

Table 1 and Figs. 1 and 2 show the mean serum IGF-I and IGFBP-3 levels in non-dialysis, dialysis, prepubertal, pubertal patients, and control group. IGF-I and IGFBP-3 levels were not significantly correlated among dialysis, non dialysis, pubertal and prepubertal groups.

The total IGF-I levels in pubertal patients were significantly higher than those in prepubertal patients $(P<0.001)$ (Fig. 1). There was no significant difference in the IGFBP-3 levels between pubertal and prepubertal patients (Fig. 2).

Mean SDSBA was $0.46 \pm 2.34$ (range -2.86 to 4.7) in dialysis and $0.27 \pm 1.93$ (range -3.3 to 3.96 ) in non-dialysis patients. Mean SDSCA was -2.43 \pm 1.69 (range -5.27 to 0.47 ) in dialysis and -3.03 \pm 1.25 (range -5.52 to -0.82 ) in non-dialysis patients. Mean SDSBA was $0.64 \pm 2.13$ (range -2.04 to 4.7 ) and SDSCA was $-3.07 \pm 1.43$ (range -5.52 to -0.82 ) in prepubertal patients. Mean SDSBA was $-0.18 \pm 2.0$ (range -2.86 to 2.54 ) and SDSCA was $-2.15 \pm 1.42$ (range -4.34 to 0.47 ) in pubertal patients. Neither IGF-I nor IGFBP-3 levels significantly correlated with SDSBA or SDSCA in either non-dialysis and dialysis patients or in pubertal and prepubertal patients (Table 1).

All the patients had normal thyroid functions (Total $\mathrm{T}_{3}=0.51-1.89 \mathrm{ng} / \mathrm{ml}$, total $\mathrm{T}_{4}=4.58-12.0 \mu \mathrm{g} /$ $\mathrm{d} l$, free $\mathrm{T}_{3}=1.83-5.54 \mathrm{pg} / \mathrm{d} l$, free $\mathrm{T}_{4}=0.93-1.77 \mathrm{ng} /$ $\mathrm{d} l, \mathrm{TSH}=0.86-7.15 \mu \mathrm{IU} / \mathrm{ml}$ ).

The maximal GH release after two different kinds of the stimulation tests was higher than $10 \mathrm{ng} / \mathrm{ml}$ in 21 patients $(n=10$ dialysis, $5 / 10$ pubertal and 


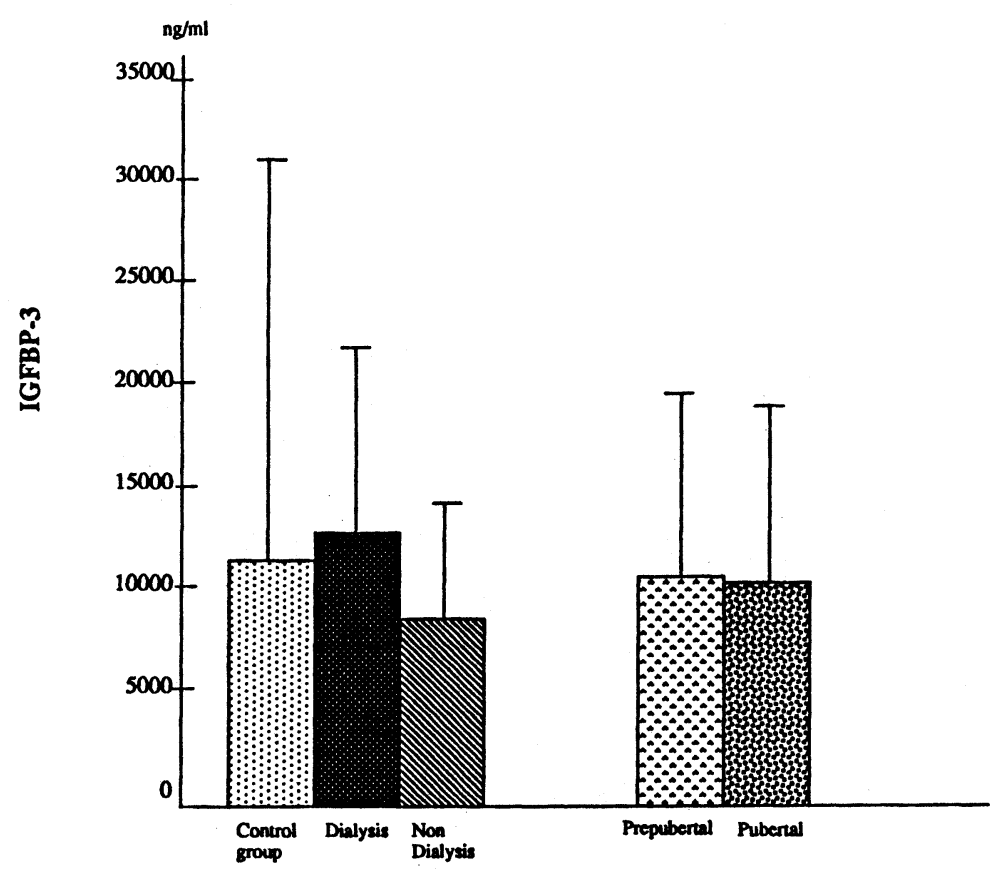

Fig. 2. Serum IGFBP-3 levels in the patients with chronic renal failure and the control group.

$\mathrm{n}=11$ non-dialysis) and $7-10 \mathrm{ng} / \mathrm{ml}$ in the remaining five patients ( $n=2$ dialysis, $1 / 2$ pubertal and $\mathrm{n}=3$ non-dialysis, $1 / 3$ pubertal), as shown in Table 1 .

\section{Discussion}

Growth retardation remains one of the most important complications of CRF. It might be explained by three factors: 1 . GH receptor dysfunction, 2. low IGF-I production other than GH receptor dysfunction, and 3. dysfunction of IGF-I action, including increased levels of IGFBP-3. We can analyse three factors described above by measuring IGF-I and IGFBP-3 levels. Although serum levels of IGF-I were found to be normal [8-10] or increased $[7,17]$ in uremia, the bioactivity of IGF-I may be found to be decreased. Serum IGF-I levels may reflect some functions of $\mathrm{GH}$ receptor and ability of IGF-I production. In our study, we have found serum IGF-I levels similar to controls. A recent study demonstrated that only the liver IGFI mRNA level was significantly reduced in uremic rats [2]. Thus it is suggested that there may be no abnormality in serum IGF-I levels in uremic patients.

IGFBP-3 has been supposed to play an inhibitory role in the growth of patients with CRF. IGFBP-3 may accumulate in circulation in renal failure, due to decreased renal excretion [18, 19]. IGF-I may be much more bound to IGFBP-3 under such condition as an increase in IGFBP-3 and that may result in a reduced free IGF-I level, which may cause growth retardation [1, 10, 20, 21]. But we found normal IGFBP-3 levels in the CRF group, as Hodson et al. [11] did.

The present study demonstrated that there were not significant differences in IGF-I and IGFBP-3 between uremic children and controls although we investigated them by using small numbers of subjects. Thus it is necessary to investigate those values in the uremic children estimating by immunoblotting assay, cross-linking assay, RIA or chromatography methods of IGFBPs [18].

Finally, in view of our data wa can conclude that growth retardation in children with CRF was not associated with abnormal serum IGF-I and IGFBP-3 levels. 


\section{References}

1. Mehls O,Tönshoff B, Blum WF, Heiiinrich U, Seidel C (1990) Growth hormone and insulin-like growth factor I in chronic renal failure. Pathophysiology and rationale for growth hormone treatment. Acta Pediatr Scand 370 (Suppl): 28-34.

2. Chan W, Valerie KC, Chan JCM (1993) Expression of insulin-like growth factor-I in uremic rats : Growth hormone resistance and nutritional intake. Kidney Int 43: 790-795.

3. Lee PDK, Hintz RL, Sperry JB, Baxter RC, Powell DR (1989) IGF binding proteins in growth-retarded children with chronic renal failure. Pediatr Res 26: 308-315.

4. Neely EK, Beukers MW, Oh Y, Cohen P, Rosenfeld RG (1991) Insulin-like growth factor receptors. Acta Pediatr Scand 372 (Suppl): 116-123.

5. Lynck RE, Furlanetto RW, Travis LB, Cunningham RJ, Mawer SM (1983) Serum Ria-Somatomedin-C (Sm-C) is depressed in children and adolescents with end stage renal disease. Kidney Int 23: 217 (Abstract).

6. Goldberg AC, Trivedi B, Delmez JA, Harter HR, Daughaday WH (1982) Uremia reduces serum insulin-like growth factor I, increases insulin-like growth factor II, and modifies their serum protein binding. J Clin Endocrinol Metab 55: 1040-1045.

7. Holly JMP, Wass JAH (1989) Insulin-like growth factors; autocrine, paracrine or endocrine? New perspectives of the somatomedin hypothesis in the light of recent developments. J Endocriol 122: 611-618.

8. Powell DR, Rosenfeld RG, Baker BK, Liu F, Hintz RL (1986) Serum somatomedin levels in adults with chronic renal failure: the importance of measuring insulin-like growth factor I (IGF-I) and IGF-II in acid chromatagraphed uraemic serum. J Clin Endocrinol Metab 63: 1186-1192.

9. Powell DR, Rosenfeld RG, Sperry JB, Baker BK, Hintz RL (1987) Serum concentrations of insulinlike growth factor (IGF)-1, IGF-2 and unsaturated somatomedin carrier proteins in children with chronic renal failure. Am J Kidney Dis 10: 287-292.

10. Blum WF, Ranke MB, Kietzmann K, Tönshoff B, Mehls O (1991) Growth hormone resistance and inhibition of somatomedin activity by excess of insulin-like growth factor binding protein in uremia.
Pediatr Nephrol 5: 593-544.

11. Cohen P, Fielder PJ, Hasegawa Y, Frish H, Giudice LC, Rosenfeld RG (1991) Clinical aspects of insulin-like growth factor binding proteins. Acta Endocrinol 124: 74-85.

12. Hodson EM, Brown AS, Roy LP, Rosenberg AR (1992) Insulin-like growth factor-I, growth hormonedependent insulin-like growth factor-binding protein and growth in children with chronic renal failure. Pediatr Nephrol 6: 433-438.

13. Schwatz GJ, Brion LP, Spitzer A (1987) The use of plasma creatinine concentration for estimating glomerular filtration rate in infants, children and adolescents. Pediatr Clin North Am 34: 571-587.

14. Tanner JM, Whitehouse RH, Takaishi M (1966) Standards from birth to maturity for height, weight, height velocity and weight velocity; British children 1965. Arch Dis Child 41: 613-635.

15. Greulich WW, Pyle SI (1959) Radiographic Atlas of Skeletal Development of Hand and Wrist. 2nd ed. Stanford, Stanford University Press.

16. Tanner JM (1962) Growth at Adolescence. 2nd ed. Blackwell, Oxford.

17. Spencer EM, Uthne KO, Arnold WC (1979) Growth impairment with elevated somatomedin levels in children with chronic renal insufficiency. Acta Endocrinol 91: 36-48.

18. Powell DR, Liu F, Baker B, Lee PDK, Belsha CW, Brewer ED, Hintz RL (1993) Characterization of insulin like growth factor binding protein-3 in chronic renal failure serum. Pediatr Res 33: 136-143.

19. Baxter RC, Martin JL (1986) Radioimmunoassay of growth hormone, dependent insulin-like growth factor binding protein in human plasma. J Clin Invest 78: 1504-1512.

20. Blum WF (1991) Insulin-like growth factors (IGFs) and IGF binding proteins in chronic renal failure: Evidence for reduced secretion of IGFs. Acta Pediatr Scand 379 (Suppl): 24-31.

21. Tönshoff B, Schaefer F, Mehls O (1990) Disturbance of growth hormone-insulin-like growth factor axis in uremia. Implications for recombinant human growth hormone treatment. Pediatr Nephrol 4: 654662. 